\title{
An Integrated Lean Supply Chain Framework for U.S. Hospitals
}

\author{
Subhajit Chakraborty \\ Department of Management and Decision Sciences \\ E. Craig Wall Sr. College of Business Administration \\ Coastal Carolina University, Conway, South Carolina 29528 \\ Email: schakrabo@ coastal.edu (Corresponding Author)
}

\author{
Jorge A. Gonzalez \\ Department of Management \\ Robert C. Vackar College of Business and Entrepreneurship \\ The University of Texas Rio Grande Valley, Edinburg, Texas 78539 \\ Email: jorge.gonzalez@utrgv.edu
}

\begin{abstract}
We apply a lean supply chain framework to the healthcare industry in the U.S., drawing support from lean systems philosophy. We conceptualize a view of the U.S. healthcare ecosystem that places a hospital and its admitted patients at the center and describes how all entities inside and outside the hospital work can implement lean principles to improve patients' quality care. This application depicts how a holistic consideration of hospital resources available in both the internal and external supply chain would increase the optimal use of such resources and ultimately serve patients. We offer propositions suggesting that an integrated supply chain perspective would be helpful for delivering high quality of care to patients admitted to the hospital. This perspective suggests that hospitals need to streamline the three types of flowsphysical product, information and financial-with elements in the internal supply chain and maintain collaborative relations with entities in their external supply chain. We discuss theoretical and practical implications of our research.
\end{abstract}

Keywords: U.S. hospital ecosystem, integrated lean hospital, supply chain management

\section{INTRODUCTION}

Despite being one of the most expensive in the world, patient care quality (PCQ) in the U.S. is not among the best (Starfield, 2000; Docteur and Berenson, 2009). Health expenditure per capita data shows that U.S. healthcare is the third most expensive globally (WorldBank, 2015), and reports of the Centers for Medicare and Medicaid Services (CMS) note that patient safety, a key aspect of quality, is mediocre (Boyer et al., 2012). Improving the quality of healthcare services available to patients and reducing the cost, thereby increasing the efficiency of treatment processes are two pressing needs of the U.S. healthcare system (Becker and Gamble, 2015).

Despite these grim facts, a potential solution may lie beyond hospital boundaries and reside with their suppliers and supporting organizations, which control the supply price and quality and delivery timeliness. For example, supply costs constitute the second highest healthcare cost component (at $31 \%$ ), closely behind the cost of facilities (at $37 \%$ ) (Schneller and Smeltzer, 2006). Also, an integration of supply flow between external entities and internal facilities is paramount. For example, hospitals are often held to the whims of the major buyer-Group Purchasing Organization (GPO) (e.g., Premier Inc., MedAssets, and Vizient) - which control about $72-80 \%$ of every healthcare dollar (Hu and Schwarz, 2011) and are supposed to leverage the purchasing power of hospitals in obtaining vendor discounts (Handfield, 2010). In sum, healthcare facilities are part of a dynamic healthcare ecosystem, and the integration of external and internal supply chain flows in such a system affects PCQ.

A healthcare ecosystem is defined as a hospital's extended healthcare facilities network that connects it with other hospitals, nursing homes, specialty care centers, rehabilitation centers and the medical fraternity at large through extensive patient sharing (Cf. Lee et al., 2013, Lee et al., 2011, Huang et al., 2010). For this reason, the potential for addressing PCQ by looking outside the hospital borders has increasingly been recognized by medical practitioners, healthcare management scholars (Johnston and Rooney, 2012; Coustasse et al., 2013) and operations management (OM) researchers (Cohen et al., 2008; Handfield, 2010). Although only limited number of studies have applied a supply chain perspective to healthcare (Rivard-Royer et al., 2002; McKone-Sweet et al., 2005; Böhme et al., 2014), they have begun to show that hospital supply chain management is crucial to reduce costs and improve healthcare quality (Schneller and Smeltzer, 2006). Nonetheless, the extant literature offers a limited perspective in that there is no available framework integrating both internal and external hospital supply chains. Studies using modeling methodologies have investigated specific characteristics of the external supply chain, such as the role of GPOs (Hu and Schwarz, 2011; Hu et al., 2012), but fail to address the internal supply chain. Empirical research, on the other hand, has considered the internal chain and addressed operating efficiency and supply chain performance (Chen et al., 2013), institutional pressures (Bhakoo and Choi, 2013) 
and cost savings (Rivard-Royer et al., 2002), but overlook the internal supply chain. We address all supply chain flows relevant to PCQ simultaneously to provide a holistic perspective helpful to identify areas for continuous improvement.

Drawing from operations literature, lean as a concept (Sugimori et al., 1977; Monden, 1981; Ōno, 1988) highlights the continuous improvement in processes by focusing on essential value-adding activities and eliminating wasteful non-value added tasks. Supply chain integration and tenets of lean philosophy have increased quality and productivity in many service industries. Lean philosophy has already been applied to healthcare conceptual articles (Peters, 2014; Sloan et al., 2014), and in empirical studies (Toussaint and Berry, 2013; Ulhassan et al., 2014), but it has been done in a piecemeal manner focusing on a few aspects of the hospital ecosystem. Lean implementation in hospitals still has challenges (Kaplan et al., 2014; Lawal et al., 2014). Currently, there is no comprehensive overarching framework that ties in hospital's internal and external supply chains. To fill this gap, we draw from lean philosophy to offer an integrated supply chain perspective of the U.S. hospital ecosystem that suggests ways for hospitals to operate more efficiently, reduce costs, and improve care quality.

\section{INTEGRATING THE INTERNAL AND EXTERNAL HOSPITAL SUPPLY CHAIN}

The Council of Supply Chain Management Professionals (CSCMP) defines supply chain management (SCM) as the "planning and management of all activities involved in sourcing, procurement, conversion, and logistics management" (CSCMP, 2011). In a hospital, the supply chain includes all the elements in its internal chain within the control of the hospital administration, as well as an external chain (Rivard-Royer et al., 2002).

Healthcare supply chain processes have three types of flows - physical product, informational, and financial (Singh et al., 2006). The effective management of these processes is crucial. Physical product flow refers to the use of products, which vary across hospitals depending on specialization. Information flows consist of electronic medicine inventory information from hospital to suppliers for automatic reordering. Healthcare team refers to the group of doctors, nurses, social workers, physical therapists, dietitians and discharge planners who work together to treat the patients. The importance of information flow among medical team members is evident. All healthcare team members who come in contact with patients should have current and accurate information on such patients' medical condition. Financial flows refer to items such as supplier bills for payment and patient collection bills (Singh et al., 2006; Kowalski, 2009).

Based on an extensive study of the extant literature in operations, nursing, healthcare and medicine, PCQ is defined here in a broad and comprehensive sense to denote the excellence of the medical care provided to hospital patients (Ware et al., 1983; Nelson and Niederberger, 1990; Dagger et al., 2007). A supply chain view of the U.S. hospital ecosystem is shown in Figure $\mathbf{1}$ and explanatory notes are given in Table 1. The elements are shown in different layers according to their frequency and intensity of interaction with patients.

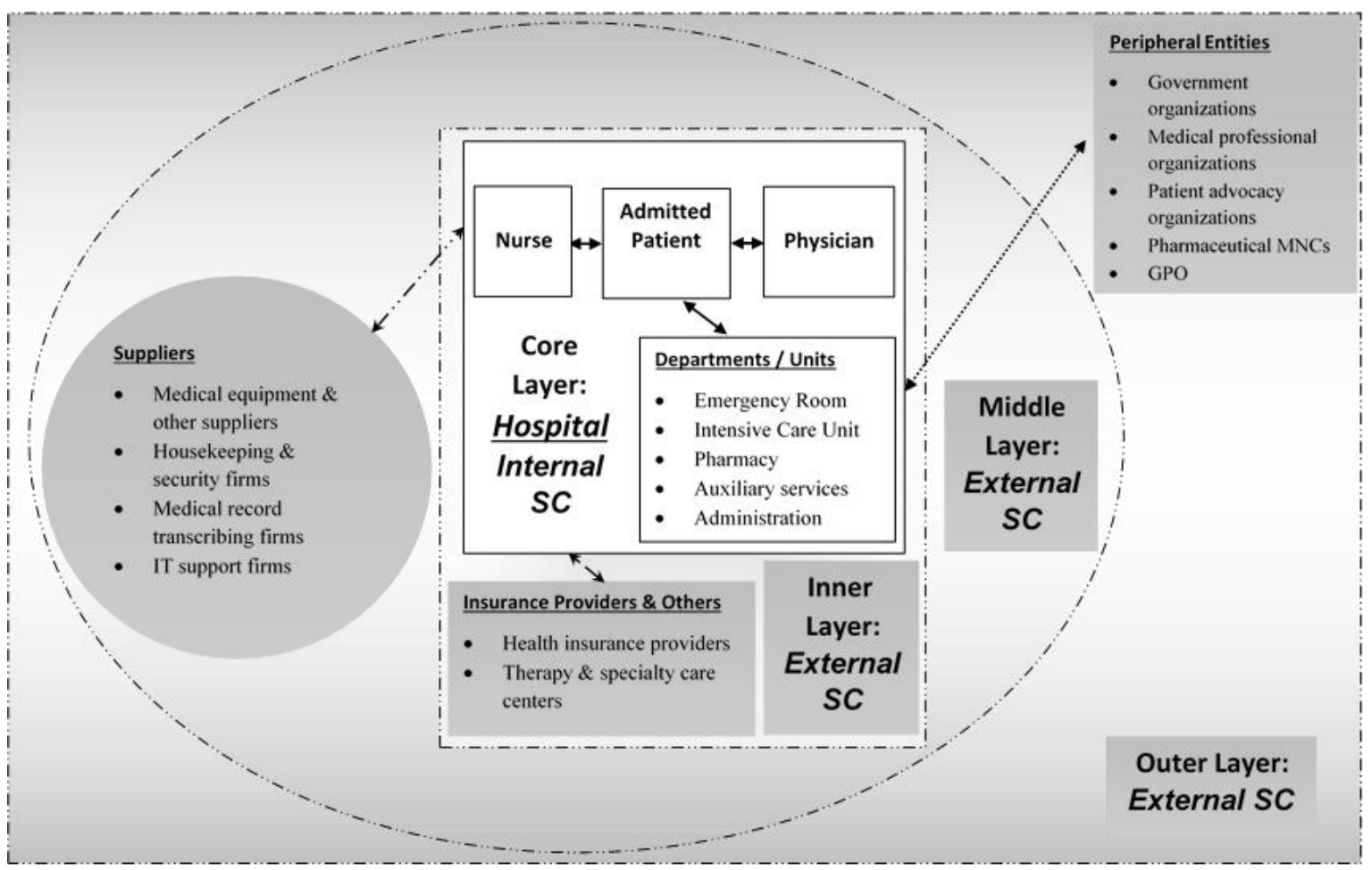

Notes: Only Tier-1 entities associated with in-patient care in U.S. hospitals are shown for brevity but some entities may have their own dependent entities. Arrows indicate material and patient, information and financial flows. Solid arrows indicate flows between a hospital's internal supply chain elements and the patient; broken arrows indicate flows with external supply chain elements.

Figure 1 U.S. Healthcare hospital supply chain framework 
Table 1 U.S. Hospital supply chain elements

\begin{tabular}{|c|c|c|}
\hline Layer & Entity & Definition \& Details \\
\hline \multicolumn{3}{|c|}{ Internal hospital supply chain (All entities are within the hospital) } \\
\hline $\begin{array}{l}\text { Core } \\
\text { layer }\end{array}$ & Hospital & $\begin{array}{l}\text { The patient in the hospital is shown at the center. The important entities within a hospital comprises:(1) } \\
\text { the doctor(s) who perform the surgery and other required medical procedures; (2) the nurse(s), who } \\
\text { usually provide the patient's pre and post procedure recovery care; and (3) other elements such as: } \\
\text { (a) administration, including billing and general management, (b) pharmacy, (c) emergency room and } \\
\text { other urgency rooms, (d) intensive care units (ICU), and (e) auxiliary services, like diagnostic testing } \\
\text { laboratory, medical counseling, blood and other organ bank, ambulances. }\end{array}$ \\
\hline \multicolumn{3}{|c|}{ External hospital supply chain (Includes all external suppliers for medications, equipment and other materials) } \\
\hline \multirow[t]{2}{*}{$\begin{array}{l}\text { Inner } \\
\text { layer }\end{array}$} & $\begin{array}{l}\text { Health insurance } \\
\text { providers }\end{array}$ & $\begin{array}{l}\text { Health insurance protects a patient from the high cost of medical care by providing coverage for } \\
\text { specific healthcare services. Three umbrella types of health insurance are common-consumer- } \\
\text { directed, fee-for-service (often known as "indemnity" plans), and managed care. These plans cover } \\
\text { medical, surgical and hospital expenses and some may cover prescription drugs, dental and } \\
\text { behavioral/mental health coverage. Health insurance providers refer to firms providing health } \\
\text { insurance services. }\end{array}$ \\
\hline & $\begin{array}{l}\text { Therapy and special } \\
\text { care centers }\end{array}$ & $\begin{array}{l}\text { Specialty care centers provide high-quality medical services such as radiation treatment, stem cell } \\
\text { transplantation and cellular therapy. Therapy centers provide developmental and rehabilitation } \\
\text { services such as speech-language therapy, pediatric occupational therapy and pediatric physical } \\
\text { therapy services. }\end{array}$ \\
\hline \multirow{6}{*}{$\begin{array}{l}\text { Middle } \\
\text { layer }\end{array}$} & IT support firms & $\begin{array}{l}\text { Information technology (IT) firms typically provides some or all IT services from computer support, IT } \\
\text { consulting, IT outsourcing, helpdesk services, data backup, disaster recovery, application hosting, and } \\
\text { email hosting to CIO level consulting, managed services, call centers. }\end{array}$ \\
\hline & $\begin{array}{l}\text { Medical record } \\
\text { transcribing firms }\end{array}$ & $\begin{array}{l}\text { Medical transcription deals with the process of converting voice-recorded reports as dictated by } \\
\text { physicians and/or other healthcare professionals into text format. Few specialized firms provide such } \\
\text { transcription service for their clients. }\end{array}$ \\
\hline & $\begin{array}{l}\text { Medical equipme } \\
\text { and other suppliers }\end{array}$ & $\begin{array}{l}\text { A firm that provides medical and other related types of equipment (e.g., beds) required by the hospital, } \\
\text { doctors and nurses for treating patients. Also included are firms that provide other furnishings and } \\
\text { supporting materials for patients such as curtains, bed sheets. }\end{array}$ \\
\hline & $\begin{array}{l}\text { Housekeeping/ } \\
\text { security firms }\end{array}$ & $\begin{array}{l}\text { A firm that that provides security services to the hospital and also performs housekeeping services } \\
\text { such as cleaning of rooms, medical equipment, laundry and stocking and keeping track of basic } \\
\text { hospital amenities in all hospital rooms especially in the emergency rooms, intensive care units. }\end{array}$ \\
\hline & $\begin{array}{l}\text { Government } \\
\text { organizations (for } \\
\text { monitoring / testing) }\end{array}$ & $\begin{array}{l}\text { Governmental agencies involved in monitoring product safety include the Food and Drug } \\
\text { Administration (FDA), Centers for Disease Control (CDC) and the Office of the Surgeon General of the } \\
\text { Department of Defense. Agencies that monitor the operation of the healthcare programs such as } \\
\text { Medicare and Medicaid are authorized to conduct audits, investigations, and inspections of any facility. }\end{array}$ \\
\hline & $\begin{array}{l}\text { Medical professional } \\
\text { organizations/ } \\
\text { fraternities }\end{array}$ & $\begin{array}{l}\text { Professional associations such as the American Medical Association (AMA) help doctors in their work } \\
\text { by uniting physicians and medical students to work on the most important professional and public } \\
\text { health issues. Professional fraternities are organizations whose primary purpose is to promote the } \\
\text { interests of a particular profession and whose membership is restricted to students in that particular } \\
\text { field of professional education or study. Common medical fraternities are: Phi Beta Pi-Theta Kappa } \\
\text { Psi, Phi Delta Epsilon, Phi Rho Sigma and Phi Chi. }\end{array}$ \\
\hline \multirow[t]{3}{*}{$\begin{array}{l}\text { Outer } \\
\text { layer }\end{array}$} & $\begin{array}{l}\text { Patient advocacy } \\
\text { organizations }\end{array}$ & $\begin{array}{l}\text { Non-profit organizations provide the patient voice in improving access to and reimbursement for high } \\
\text { quality healthcare through regulatory and legislative reform at the state and federal levels. Examples } \\
\text { are National Patient Advocate Foundation, HealthHIV, and the National Association for Hearing and } \\
\text { Speech Action. }\end{array}$ \\
\hline & $\begin{array}{l}\text { Pharmaceutical } \\
\text { multinational } \\
\text { companies }\end{array}$ & $\begin{array}{l}\text { Pharmaceutical firms could be involved in developing, producing, and marketing drugs licensed for } \\
\text { use as medications. Pharmaceutical companies are allowed to deal in generic and/or brand } \\
\text { medications and medical devices. Dosage forms include tablets and capsules, injectables, creams, } \\
\text { ointments, inhalants, and solutions. }\end{array}$ \\
\hline & $\begin{array}{l}\text { Group Purchasing } \\
\text { Organization }\end{array}$ & $\begin{array}{l}\text { A group purchasing organization (GPO) is an entity that helps healthcare providers-such as hospitals, } \\
\text { nursing homes and other health agencies realize efficiencies by aggregating purchasing volume into } \\
\text { bulk and using that leverage to negotiate discounts with the item suppliers. Premier Inc., MedAssets, } \\
\text { Vizient, Intalere, Cardinal Health, McKesson Pharmaceutical, AmerisourceBergen, HealthTrust } \\
\text { Purchasing Group (HPG), Department of Veterans Affairs and Provista are some of the common large } \\
\text { GPOs by the total number of member hospital beds. }\end{array}$ \\
\hline
\end{tabular}

Notes: Entities are drawn from an extensive review of extant healthcare and operations literature and articles on quality of patient care in the business press. 
A hospital's internal supply chain is depicted as the core layer comprising entities that most hospitals have in-house and interact with a patient (Langtree, 2013): the healthcare team, patient rooms, emergency and urgency rooms, intensive care units, hospital administration including general management and billing, in-house pharmacy, and auxiliary services such as diagnostic testing laboratory, medical counseling, blood and organ banks, and transportation services (e.g. ambulances). A hospital's external supply chain is depicted in three concentric layers representing entities that interact with the hospital to deliver patient care, although many may not directly interact with patients. The inner layer comprises healthcare-related firms such as health insurance providers and therapy and specialty care provider firms. The middle layer entities consist of firms that provide services such as information technology support, medical record transcribing, equipment and other suppliers and housekeeping and security related services, some of which may be outsourced. The middle layer entities may not interact directly with a patient (i.e., there may be an inner layer entity between patients and these middle layer entities). Outer layer entities may not interact with patients at all, but still are a part of the healthcare system. Outer layer entities include external supporting organizations like government organizations for monitoring and testing drugs, medical professional organizations (e.g., AMA) and medical fraternities (e.g., Phi Delta Epsilon), patient advocacy organizations (e.g., the National Patient Advocate Foundation), medical research universities and pharmaceutical corporations and GPOs which negotiate the purchasing prices of all items on behalf of the member hospitals. The framework applies to only hospitaladmitted/in-patients who interact with most of these entities, leaving out-patients. Most out-patients, because of the simple nature of their sickness/ailments, may not need to come back to visit the hospital and thus may not interact with many of the entities depicted here.

Next, we address those aspects that have the greatest potential impact on PCQ. We first explore technology integration, a key aspect from the internal hospital supply chain, and then focus on supplier relationships, which are important for the management of the external hospital supply chain.

\subsection{Technology Integration}

Technology integration refers to the interconnectedness of the different technological software and hardware systems implemented in hospitals ( $\mathrm{Li}$ and Lin, 2006; Leidner et al., 2010). The tight integration present in software systems that some hospitals use reduce operational uncertainty by providing coordination, visibility, and easy information sharing across transactions (Hendricks et al., 2007; Leidner et al., 2010). Easy access to integrated data about the latest in-house hospital stock levels may make it easier for hospital administrators to transact business with other entities, both within and outside the hospital (Huber and McDaniel, 1986; Saeed et al., 2005).

Both extant healthcare literature and the business press routinely highlight medical errors, which happen because of inaccurate information available to physicians and nurses (Devaraj and Kohli, 2000; Angst et al., 2011; Queenan et al., 2011). Healthcare scholars acknowledge that hospital management needs to have access to the most up-to-date information when they need it to be able to make decisions (Allen, 2013; Waldfogel, 2013) which includes summarized patient information drawn from hospital support systems like labs and pharmacies, accounting and financial information (Vest and Gamm, 2010; Jarousse, 2016). It is crucial for all different software and hardware systems implemented by various departments to "talk" to each other and exchange information when needed. In other words, capitalizing on technology requires distinct information technology (IT) systems to be well integrated (Albani and Lee, 2007).

\subsection{Supplier Relationship Management}

Supplier relationship management is a perspective that uses social ties and interpersonal contact between a focal firm and its suppliers to monitor, control and encourage desirable supplier behavior (Noordewier et al., 1990; RivardRoyer et al., 2002; Das et al., 2006). A firm and its suppliers using the same technological systems such as an enterprise resource planning (ERP) system, customer relationship management (CRM) application, as well as relational capital development efforts such as cross-functional involvement and joint problem solving are likely to communicate inventory demands and stock supply positions quickly (Talluri and Sarkis, 2002, Das et al., 2006).

The marketing and OM literature depict buyer-supplier relationship management as a multi-dimensional phenomenon that comprises supplier flexibility, supplier assistance, supplier information exchange, supplier monitoring, continuity expectation and quality of supplies (Noordewier et al., 1990; Chung, 2012; Lumineau and Henderson, 2012). Unforeseen requests for adjustments in stock levels and emergency deliveries are opportunities for supplier flexibility to change production and delivery schedules to meet firm requests (Noordewier et al., 1990; Chan et al., 2008). The extent to which suppliers help firms by going beyond contractually bound conduct denotes supplier assistance (Noordewier et al., 1990; Dyer et al., 1998; Janda et al., 2002). Supplier information exchange refers to the frequency and type of information provided by suppliers to the firms (Noordewier et al., 1990; Trapero et al., 2012). Supervisory actions that firms need to take to ensure supplier performance represents supplier monitoring (Noordewier et al., 1990; Gavronski et al., 2011). Continuity expectation describes long-term expectations of a lasting relationship between firms and their suppliers (Noordewier et al., 1990; Villena et al., 2013) over and beyond the honeymoon period (Hammervoll, 2011). Quality of supplies delivered by the supplier (Larson, 1994; Gunasekaran et al., 2004) is also important in a long-term relationship. Hospitals may need to focus on improving their supplier relationship management (Rohner and Mettler, 2010; Goodman and Jones, 2013).

\subsection{Lean Orientation}

The concept of lean started with "just-in-time" or "pull" processes focused on reducing inventory to reduce cost and improve efficiency (Sugimori et al., 1977; Monden, 1981; Ōno, 1988). This approach later evolved to incorporate waste management and strive for continuous quality improvement. A lean business strategy strives to improve firms' operating performance by reducing inventory and getting all firm 
components to work efficiently (Shah and Ward, 2003; Dahlgaard et al., 2011; Azadegan et al., 2013). Lean orientation includes material flow management, continuous quality improvement and waste management (Li et al., 2005; Mackelprang and Nair, 2010; Azadegan et al., 2013). Material flow management refers to the continuous flow of production work in process without hindrance through the production factory or service generation unit (Benton et al., 2010; Petersen and Wohlin, 2011; Chongwatpol and Sharda, 2013). Continuous quality improvement refers to incremental improvement in quality standards of a firm on a regular periodic basis and is one of the key pillars of lean implementation (McFadden et al., 2014). Waste management refers to identifying, controlling and eliminating waste, that is, processes that add no value to the product, service or customer (Womack and Jones, 2010). In a hospital, waste can occur in areas such as transportation of patients across hospital rooms, ICUs and surgery rooms, inventory of medical equipment and supplies, and patients waiting for procedures and surgeries (Waring and Bishop, 2010), among others.

In order to determine the specific lean practices to implement, hospitals should consider the entire concept of a "service package" (Krajewski et al., 2002) they provide, which would include not only the explicit service, but also implicit services, facilitating goods, and supporting facilities. In a healthcare context, treating the illness that the patient suffers by giving appropriate medicine and/or performing the required medical procedures would constitute explicit services. Other important elements would include the hospital check-up rooms, which are supporting facilities. The medical equipment utilized in providing the explicit service, like a physician's stethoscope and sphygmomanometer, a surgeon's knife and other medical technology-related items (e.g. robots) would be facilitating goods. Implicit services would comprise procedures that accompany or occur after the provision of the explicit service, such as checking the patient for related and unrelated complications that may arise from administering medicines and procedures or from allergies the patient may have had before the explicit service. Another example of implicit services occurring after the fact would be the provision counseling or therapy in cases of life-threatening illnesses like cancer or traumatic procedures like the amputation of limbs.

\section{LEAN OPERATIONS AND THE INTERNAL SUPPLY CHAIN}

Implementing patient and material flow management would imply the hospital following efficient patient admission and discharge procedures. An effective implementation would include, for example, that major hospital facilities like ICUs as well as minor equipment such as drip stands are available when required so procedures are not delayed (Alexander et al., 1996; Butler \& Leong, 2000; Cook and Rasmussen, 2005; Devaraj et al., 2013; Goldstein et al., 2002; Harper, 2002; Hay, 2003). To implement material flow management, hospitals could employ scheduling software that factor in patients' medical conditions and needs along with the hospital room and equipment availability information together to streamline both patient and material flow.

Continuous quality improvement, which focuses both on learning from problems and continuously finding opportunities to increment quality, is a key element of lean implementation in hospitals. First, continuous quality improvement would include healthcare teams internalizing the lessons learnt from past mistakes on patient safety so as not to repeat them. To accomplish this, Hospitals could use operational data from electronic clinical information systems to plan its staffing of doctors, nurses and other employees and up-to-date advanced medical equipment and technologies while performing all medical procedures. Healthcare teams in hospitals must strive to perform the correct medical procedures the very first time that they treat a patient (Albani and Lee, 2007; Axon and Williams, 2011; Butler and Leong, 2000; Goldstein et al., 2002). Second, hospitals can also continuously find opportunities to improve quality. Hospitals need to keep abreast of the latest technological breakthroughs in the field (Hay, 2003). Upgraded physical infrastructure of labs, operation theatres and intensive care units (ICU) and other more basic elements like hospital beds would also be relevant (Butler and Leong, 2000; Goldstein et al., 2002). For instance, hospitals can inculcate their employees on the use of the newest equipment and medical technology. They may also guide their employees to share the best practices in the use of such equipment among one another, which would be consistent with one of Deming's (1993) 14-point recommendations-to encourage cooperation among all employees to improve quality and productivity.

Applying waste management to healthcare would support the use of a "pull" production system wherein all supplies are inventoried as and when required, and where hospitals push suppliers to achieve shorter lead-times. Implementing lean waste management would include hospitals streamlining their own ordering, receiving, handling paperwork from suppliers, and optimally using medical consumables to eliminate waste (Hirano, 1995; Labarere et al., 2001; Wakefield et al., 2005; Wearmouth, 2001).

Lean operations also concern the attributes of the physical environment. A clean and organized workplace is a key component of the 5-S philosophy, an overall approach to lean production systems (Hirano, 1995). The physical environment would include the aspect of the surroundings in which healthcare is delivered, such as whether the facilities and equipment used are orderly, the degree of pleasantness of hospital room atmosphere, and the clarity of signs and directions to different facilities within hospitals. Effective housekeeping is an essential method of maintaining cleanliness and removing and minimizing wastes in hospital departments as it helps streamline the entry and discharge procedures in a hospital (Labarere et al., 2001; Wakefield et al., 2005; Wearmouth, 2001).

Both the supply and demand for hospital services need to be balanced for hospitals to function well. The preparation of the initial diagnostic and consultation report by the physician, taking the patient to the emergency room (ER) department (if it is an urgent case) and transferring the patient to specialized medical suites such as the operating room (if the patient needs surgery) are internal supply chain related activities. The demand related activities incorporates 
processes for managing the flow of patients (Heineke, 1995) with the aim of having no more than the maximum number of patients that the hospital can handle. Failures in patient or material flow in the hospital, such as excessive patient wait for admission and medical procedures, may have a direct negative impact on the quality and overall effectiveness of service performance (Baltacioglu et al., 2007).

\section{LEAN OPERATIONS AND THE EXTERNAL SUPPLY CHAIN}

Aside from the integration among the entities in the internal supply chain, the integration of external supply chain entities is crucial to the hospital's implementation of lean practices and its ability to serve its patients. Lean systems theory (Flynn et al., 1995; Kaynak, 1997, 2002; Monden, 1981; Ōno, 1988; Shah and Ward, 2003; Sugimori et al., 1977) emphasizes that firms must have inventory that is reduced but also available "just-in-time" when they need it. Healthcare literature also supports this assertion (Dranove and White, 1987, 1989; Schneider and Mathios, 2006). This reduction of inventory that does not harm availability of resources suggests the implementation of a "pull" inventory system, which cannot be accomplished by a hospital alone. Instead, it requires an integrated system built on supplier collaboration. For this reason, the strength of the hospital's supplier relationships become imperative for the implementation of lean practices within the hospital.

Supplier relationship management has a strong role in a hospital's continuous quality improvement efforts (McLaughlin et al., 2004). In addition to strong leadership support and commitment, successful and sustained continuous quality improvement initiatives require hospitals to develop long term and mutually beneficial partnerships with key suppliers (LeBrasseur et al., 2002) to reduce inventory and yet meet patient care service quality standards (Dahlgaard et al., 2011). Lean waste management can also be implemented through a "pull" inventory management system (Womack and Jones, 2010; Zidel, 2006) built on supplier cooperation (Dahlgaard et al., 2011). For example, effective material restocking processes may involve batch deliveries that are more frequent but smaller, or the faster rotation of supplies, to reduce the amount of space used in internal warehouses and the cash tied-up in inventory (Graban, 2011). For these reasons, scholars have noted that relationships with hospital suppliers is one of the characteristics of a successful continuous quality improvement implementation (LeBrasseur et al., 2002).

In sum, applying a comprehensive lean orientation in hospitals would constitute integrating entities in the internal hospital supply chain such that they can seamlessly exchange information, as well as the presence of effective collaborative relationships among external hospital supply chain entities. Therefore, our two propositions note:

Proposition 1: Technology integration among entities in the internal hospital supply chain is positively related to the hospital's lean orientation.

Proposition 2: Effective supplier relationship management with entities in the external hospital supply chain is positively related to the hospital's lean orientation.
A hospital's lean orientation based on technological and knowledge sharing in the internal supply chain and effective supplier relationships in the external supply chain is crucial. Such a lean orientation can have a positive impact on the care quality of patients. This outcome can be considered the primary purpose of hospitals and the ultimate goal of the implementation of lean practices in a health care context.

\section{Patient Care Quality (PCQ)}

Based on a synthesis of the multi-dimensional nature of care quality discussed in extant literature we conceptualize PCQ as comprising the following four quality dimensions: interpersonal, technical, environmental and administrative quality (Dagger et al., 2007; Gill and White, 2009). Interpersonal quality reflects the relationship developed and the dyadic interplay that occurs between the healthcare team and the patient, including treating patients with respect, listening to their concerns, giving them personalized attention, and answering their questions and those by their kin. Technical quality reflects the expertise, professionalism, and competency of the healthcare team in care delivery. It is concerned with administering the appropriate medical care required, administering only the required laboratory testing (e.g., X-rays, blood work), and the appropriate qualifications and task effectiveness of healthcare team members. Environmental quality comprises hospital atmosphere, such as cleanliness and order, and tangibles like hospital bed and equipment quality and includes hospital rooms and laboratory design, aesthetically pleasing colors and décor, pleasant temperature, sufficient lightning, comfortable furniture, and patient friendliness (e.g., door handles are at appropriate height to accommodate patients in wheelchairs). Administrative quality facilitates the provision of care centered on the alleviation and cure of ailments and disease while adding value to the patient's care and well-being. It comprises internal hospital services' ability to interact efficiently with other units (e.g. pathology communicating with surgical procedures) and the reduction of wait time, the provision of a wide range of patient support services, and accurate hospital records and documentation (e.g., billing).

Service quality is an important outcome of lean implementation (Dean Jr and Snell, 1996; Fullerton and McWatters, 2001). Lean philosophy (Sugimori et al., 1977; Monden, 1981; Ōno, 1988) specifically posits that reducing waste help firms identify and eliminate rework. Lean philosophy explains the positive effect of a hospital's internal lean practices on PCQ. By implementing an internal lean orientation, hospital leadership can optimize material and patient flow. For example, physicians who master medical diagnosis and treatment procedures are likely to use the most effective treatment the first time around, which prevents waste (Bohmer, 2009). Second, physicians and other team members (e.g. nurses) could also master the interpersonal quality dimension. The business press often notes that U.S. physicians and nurses do their job but may not offer comfort to their patients, highlighting the need for hospital team members to get to know their patients personally and still be efficient in their job (Altman, 2014; Martin, 2014). Nonetheless, personal care can be accomplished efficiently. Physicians and healthcare team members are the ones qualified to determine the time and effort patients need (in spite of what the patient or their kin 
may think) and to find elements creating waste. For example, physicians performing nursing or counseling job or nurses providing housekeeping directions would constitute waste. A lean orientation would ensure that patients get the requisite time and necessary medical treatment from the right people. Following the discussions in extant literature (Marley et al., 2004; Hudelson et al., 2008), it is suggested that healthcare team members keep the patient informed about the required medical treatment and its side-effects and empathize with patients (Chen, 2008). A financial resource coordinator should also be involved so that patients/kin know what to expect in the medical bills (Torrens, 2010).

Patient and material flow are related to the interpersonal and technical aspects of PCQ. Hospitals should only admit the number of patients they can handle efficiently and manage the flow of patients in critical condition. Smooth material and patient flow in the hospital will help decrease the average wait times for patients before their surgery or other medical procedures (Baltacioglu et al., 2007). Long wait times add stress to patients (Paterson et al., 2006), complicate ailments, cause additional medical procedures to be required, and may even result in preventable deaths (Derlet and Richards, 2000).

Continuous quality improvement and waste reduction, the two pillars of lean philosophy, are related to the technical, environmental and administrative dimensions of PCQ. Continuous quality improvement includes managing the physical elements of a patient's environment, such as making sure that hospital bed, clothes and equipment are clean and disinfected (Aiken et al., 2008) in order to prevent complications (Pittet et al., 2000; Dowd, 2011). Support from the hospital's administrative department is crucial to PCQ (Conway, 1997; Bokar and Perry, 2007). For example, reception is the first hospital department that patients interact and often they form their first impression about the hospitals based on this interaction. Similarly, billing is another crucial department with whom every patient or their kin have to interact. Billing departments should explain all the details about charges to the patient or their kin, the role of various insurance providers in general and answering potential questions from patients or their kin about types of charges, including which and how hospital charges are covered by insurance. As value addition and waste reduction (Toussaint and Berry, 2013) are important concerns, implementing lean principles encourages healthcare team members to continuously develop expertise in their field and share their knowledge with one another through collaboration (SuiPPheng and Khoo, 2001). Based on the above discussions it is proposed that a hospital's lean orientation is positively related to all four dimensions of its PCQ - interpersonal, technical, environmental and administrative quality. Therefore:

Proposition 3: A hospital's lean orientation is positively related to its patient care quality.

\section{DISCUSSION AND CONCLUSION}

Our conceptual framework for the adoption of a lean orientation by integrating internal and external health care supply chain entities has several important implications for medical practitioners and hospital operations, particularly in the U.S. First, hospitals need to focus on different aspects of
PCQ, especially the interpersonal, environmental and administrative quality dimensions. Hospital senior administration needs to ask physicians to pay more attention to treating patients more like human beings and less like plain numbers. On a similar note, nurses could be better trained to emphasize with patients trying to understand their pain and suffering better and also empathize with them. To improve the environmental quality, housekeeping needs to follow all hospital rules to keep the hospital wards neat, organized, clean and disinfected. Hospital housekeeping and nurses have a special responsibility to ensure that hospitalacquired infections do not spread and cause damage to patients. The administrative quality dimension could be improved by better training its billing and other administrative staff to give more importance to the patient and/or their kin in clarifying their questions. Hospital's administrative staff should be knowledgeable about the Affordable Care Act of 2010 and how the political and legal environment surrounding it affects current patients.

Second, to have an integrated hospital that takes into account external supply chain factors for planning its internal operations, optimized flows among entities can be achieved by implementing enterprise-wide technology solutions (e.g., ERP packages like Cerner and Oracle). Hospitals with low levels of physician employment need to use customer relationship management (CRM) systems to positively influence patient care and satisfaction (Dobrzykowski et al., 2015). Integrating all technological systems in a hospital so they exchange information in real time and using systems such as electronic medical records (EMR) is another example. Although many U.S. hospitals are already using patient information systems, it tends not to be uniform across all hospitals and departments (Schroeder, 2015). Even today, not all hospital systems interact with each other to communicate the most up-to-date information (Whitney, 2015). Also, although many hospitals in the U.S. already use emergency and operating room scheduling software, adoption is not widespread, particularly in small-cities and rural areas (Bodenheimer and Pham, 2010; Zaghloul and El Enein, 2010).

Third, to maximize the positive effect of the implementation of lean practices on quality of care delivered (Dobrzykowski et al., 2016); hospitals should focus on all three aspects-material flow management, continuous quality improvement and waste management. Continuous quality improvement includes healthcare teams internalizing lessons learned from past mistakes to avoid repeating them. One example targeting continuous quality improvement is hospitals using operational data from electronic clinical information systems such as an electronic health record (EHR) platform to plan staffing of doctors, nurses and other employees. Many smaller and rural hospitals have caught up on this (Chen et al., 2009; Jha et al., 2009; Graetz et al., 2014). Nonetheless, there is evidence that many hospitals are not using up-to-date advanced medical equipment and newer technologies such as electronic aspirin, needle-free diabetes care (MacRae, 2013) or advanced robotics to assist complicated surgeries (Albani and Lee, 2007; Gomes, 2011). Hospitals need to streamline their own ordering, receiving and other paperwork from suppliers all items, especially their emergency medicinal stocks and better train all their healthcare teams to optimally use all medical consumables to eliminate waste (Hirano, 1995; Wakefield et al., 2005). 
Some studies report that patient surgeries are delayed due to the absence of operating rooms, medical staff such as surgeons or anesthetists, or even medicines and correct medical equipment (Wong et al., 2010; Kumar and Gandhi, 2012). Hospitals with a lean orientation should be able to identify potential waste and delays that do not add value to the patient and eliminate such activities (Graban, 2011; Toussaint and Berry, 2013).

Fourth, hospitals need to monitor and control suppliers in the middle layer of the external supply chain and foster collaboration with outer layer entities by implementing the following steps. First, they need to ensure that medical equipment and other item suppliers respond quickly to all requests. Second, they need to involve their key suppliers when replacing existing equipment and the redesign of existing products such as with better and more efficient ones. Third, hospitals need to provide suppliers with long-range requirement forecasts, especially to their medication and equipment suppliers. Fourth, hospitals should strive to nurture a mutually beneficial relationship with their key suppliers who could be trusted to resolve issues proactively (Goodman \& Jones 2013). Fifth, given continued technological changes in the health care technology, hospitals should to encourage re-training of healthcare team members and supplier quality certifications and documentation of operations (e.g. manuals describing changes in the operations of a new CT scan machine or using needle-free diabetes care kits) to stimulate defect-free quality in all of its products, services and supplies.

\subsection{Limitations and Future Decisions}

The conceptual framework may have a few limitations. Because the framework was created with the U.S. healthcare ecosystem in mind, it may be applicable to only U.S. healthcare directly and may need a few modifications to be applied to other countries. Further, as only hospital inpatients were included, caution should be taken with any applications to out-patients. Extant models have been associated mostly with disease or ailment-specific measures that reflect only specific aspects of medical care quality. For example, the 30-day risk-standardized mortality and readmission rates for ailments such as acute myocardial infarction (heart attack) and pneumonia are common quality metrics. While using detailed measures is helpful to address specific outcomes such as hospital-acquired infections, such measures may fail to adequately reflect important dimensions of care quality such as interpersonal, environmental and administrative dimensions. Our conceptual framework was intended to address such limitations

The supply chain conceptualization of a hospital ecosystem could spur empirical studies testing these propositions. Healthcare studies will benefit from including factors beyond the immediate control of hospitals such as their equipment and medicine suppliers and other entities in the external supply chain layers, such as insurance providers. We take the first step towards building a unified supply chain theory for healthcare using a hospital-centric supply chain view keeping the hospital-admitted patients at the core. The proposed framework has the short-term objective of implementing lean practices in hospital, as well as the long- term objective of delivering the highest quality care to its admitted patients.

In sum, hospitals could systematically streamline all three types of flows-physical product, information and financial-among the different units in their internal supply chain, optimize all three types of flows with the two entities of the inner layer of external supply chain and invest resources such as dedicated teams, IT systems, regular interaction. They should also perform routine audits to monitor supplier relations with middle-layer external supply entities. Hospitals could establish and maintain collaborative rapport with entities in the outer layer of their external supply chain. Hospitals should also invest significant effort in building goodwill and communication channels and network with external supply chain entities such as medical practitioners, pharmaceutical firms and faculty in research universities in the external supply chain. Both the hospitals and entities in their outer layer would benefit from a close relationship that is solidified with mutual site visits and joint collaborative experiments.

\section{REFERENCES}

Aiken, L.H., Clarke, S.P., and Sloane, D.M. (2008). Effects of hospital care environment on patient mortality and nurse outcomes. Journal of Nursing Administration, 38(5), pp. 223229.

Albani, J.M., and Lee, D.I. (2007). Virtual reality-assisted robotic surgery simulation. Journal of Endourology, 21(3), pp. 285287.

Alexander, J. A., Halpern, M. T., \& Lee, S. Y. D. (1996). The shortterm effects of merger on hospital operations. Health Services Research, 30(6), pp. 827-847.

Allen, M. (2013). How Many Die From Medical Mistakes in U.S. Hospitals? available

https://www.propublica.org/article/how-many-die-frommedical-mistakes-in-us-hospitals (accessed 19 April 2016).

Altman, L.K. (2014). A Patient's-Eye-View of Nurses, The New York Times, 10 February 2014 available at: https://well.blogs.nytimes.com/2014/02/10/a-patients-eyeview-of-nurses/?_r=1 (accessed 19 April 2016).

Angst, C.M., Devaraj, S., Queenan, C.C., and Greenwood, B. (2011). Performance Effects Related to the Sequence of Integration of Healthcare Technologies. Production and Operations Management, 20(3), pp. 319-333.

Axon, R., \& Williams, M. V. (2011). Hospital readmission as an accountability measure. The Journal of the American Medical Association, 30(5), pp. 504-505.

Azadegan, A., Patel, P.C., Zangoueinezhad, A., and Linderman, K. (2013). The effect of environmental complexity and environmental dynamism on lean practices. Journal of Operations Management, 31(4), pp. 193-212.

Baltacioglu, T., Ada, E., Kaplan, M.D., Yurt, O., and Kaplan, Y.C. (2007). A New Framework for Service Supply Chains. Service Industries Journal, 27(2), pp. 105-124.

Becker, S., and Gamble, M. (2015). The 8 biggest healthcare issues in 2015 so far available at: http://www.beckershospitalreview.com/hospitalmanagement-administration/the-8-biggest-healthcare-issuesin-2015-so-far.html (accessed 6 February 2017).

Benton, W.C., Cochran, J.J., Cox, L.A., Keskinocak, P., Kharoufeh, J.P. and Smith, J.C. (2010), Just-In-Time/Lean Production Systems. Wiley Encyclopedia of Operations Research and Management Science. John Wiley, and Sons, Inc, New York, NY.

Bhakoo, V., and Choi, T. (2013). The iron cage exposed: Institutional pressures and heterogeneity across the 
healthcare supply chain. Journal of Operations Management, 31(6), pp. 432-449.

Bodenheimer, T., and Pham, H.H. (2010). Primary Care: Current Problems and Proposed Solutions. Health Affairs, 29(5), pp. 799-805.

Böhme, T., Williams, S., Childerhouse, P., Deakins, E., and Towill, D. (2014). Squaring the circle of healthcare supplies. Journal of Health Organization and Management, 28(2), pp. 247265.

Bohmer, R.M.J. (2009). Designing Care: Aligning the Nature and Management of Health Care, Harvard Business School Publishing, Boston, Massachusetts.

Bokar, V., and Perry, D.G. (2007). Different roles, same goal: risk and quality management partnering for patient safety. By the ASHRM Monographs Task Force, Journal of healthcare risk management, 27(2), pp. 17-23, 25.

Boyer, K.K., Gardner, J., and Schweikhart, S. (2012). Process quality improvement: An examination of general vs. outcome-specific climate and practices in hospitals, Journal of Operations Management, 30(4), pp. 325-339.

Butler, T., \& Leong, G. (2000). The impact of operations competitive priorities on hospital performance. Health Care Management Science, 3(3), pp. 227-235.

Chan, F.T.S., Bhagwat, R., and Wadhwa, S. (2008). Study on suppliers' flexibility in supply chains: Is real-time control necessary?. International Journal of Production Research, 47(4), pp. 965-987.

Chen, C., Garrido, T., Chock, D., Okawa, G., and Liang, L. (2009). The Kaiser Permanente Electronic Health Record: Transforming and Streamlining Modalities of Care, Health Affairs, 28(2), pp. 323-333.

Chen, D.Q., Preston, D.S., and Xia, W. (2013). Enhancing hospital supply chain performance: A relational view and empirical test. Journal of Operations Management, 31(6), pp. 391-408.

Chen, P.W. (2008). Taking Time for Empathy, The New York Times, 25 September 2008 available at: http://www.nytimes.com/2008/09/26/health/chen25.html (accessed 19 April 2016).

Chongwatpol, J., and Sharda, R. (2013). Achieving Lean Objectives through RFID: A Simulation-Based Assessment. Decision Sciences, 44(2), pp. 239-266.

Chung, J.E. (2012). When and How Does Supplier Opportunism Matter for Small Retailers' Channel Relationships with the Suppliers? Journal of Small Business Management, 50(3), pp. 389-407.

Cohen, A.B., Restuccia, J.D., Shwartz, M., Drake, J.E., Kang, R., Kralovec, P., Holmes, S.K., Margolin, F., and Bohr, D. (2008). A Survey of Hospital Quality Improvement Activities. Medical Care Research and Review, 65(5), pp. 571-595.

Conway, J.B. (1997). Breaking down professional silos: the potential of integrated management. Radiology Management, 19(3), pp. 30-34.

Cook, R., \& Rasmussen, J. (2005). "Going solid": A model of system dynamics and consequences for patient safety. Quality and Safety in Health Care, 14(2), pp. 130-134.

Coustasse, A., Tomblin, S., and Slack, C. (2013). Impact of RadioFrequency Identification (RFID) Technologies on the Hospital Supply Chain: A Literature Review. Perspectives in Health Information Management, 10(Fall), pp. 1-17.

CSCMP (2011). Council of Supply Chain Management Professionals, available

at: https://cscmp.org/iMIS0/CSCMP/ (accessed 19 April 2016).

Dagger, T.S., Sweeney, J.C., and Johnson, L.W. (2007). A Hierarchical Model of Health Service Quality: Scale Development and Investigation of an Integrated Model. Journal of Service Research, 10(2), pp. 123-142.

Dahlgaard, J.J., Pettersen, J., and Dahlgaard-Park, S.M. (2011). Quality and lean health care: a system for assessing and improving the health of healthcare organisations. Total
Quality Management, and Business Excellence, 22(6), pp. 673-689.

Das, A., Narasimhan, R., and Talluri, S. (2006). Supplier integration - Finding an optimal configuration. Journal of Operations Management, 24(5), pp. 563-582.

Deming, W. E. (1993). The New Economics for Industry, Government, Education. Cambridge, MA: Massachusetts Institute of Technology, Center for Advanced Engineering Study.

Dean Jr, J.W., and Snell, S.A. (1996). The strategic use of integrated manufacturing: An empirical examination. Strategic Management Journal, 17(6), pp. 459-480.

Derlet, R.W., and Richards, J.R. (2000). Overcrowding in the nation's emergency departments: Complex causes and disturbing effects. Annals of emergency medicine, 35(1), pp. 63-68.

Devaraj, S., and Kohli, R. (2000). Information technology payoff in the health-care industry: a longitudinal study. Journal of Management Information Systems, 16(4), pp. 41-67.

Devaraj, S., Ow, T. T., \& Kohli, R. (2013). Examining the impact of information technology and patient flow on healthcare performance: A Theory of Swift and Even Flow (TSEF) perspective. Journal of Operations Management, 31(4), pp. 181-192.

Dobrzykowski, D.D., Callaway, S.K., and Vonderembse, M.A. (2015). Examining Pathways from Innovation Orientation to Patient Satisfaction: A Relational View of Healthcare Delivery. Decision Sciences, 46(5), pp. 863-899.

Dobrzykowski, D.D., Mcfadden, K.L., and Vonderembse, M.A (2016). Examining pathways to safety and financial performance in hospitals: A study of lean in professional service operations. Journal of Operations Management, 4243(2016), pp. 39-51.

Docteur, E., and Berenson, R.A. (2009). How Does the Quality of U.S. Health Care Compare Internationally? Urban Institute. The Robert Wood Johnson Foundation, New York, NY.

Dowd, M. (2011). Giving Doctors Orders. The New York Times, 12 April 2011 available at: http://www.nytimes.com/2011/04/13/opinion/13dowd.html (accessed 19 April 2016).

Dranove, D., \& White, W. D. (1987). Agency and the Organization of Health Care Delivery. Inquiry, 24(4), pp. 405-415.

Dranove, D., \& White, W. D. (1989). Agency theory: new insights into the health care industry. The Journal of medical practice management: $M P M, 4(3)$, pp. 165-169.

Dyer, J.H., Cho, D.S., and Chu, W. (1998). Strategic Supplier Segmentation: The Next Best Practice in Supply Chain Management. California Management Review, 40(2), pp. 57 77.

Flynn, B. B., Sakakibara, S., \& Schroeder, R. G. (1995). Relationship between JITand TQM: Practices and Performance. Academy of Management Journal, 38(5), pp. 1325-1360.

Fullerton, R.R., and Mcwatters, C.S. (2001). The production performance benefits from JIT implementation. Journal of Operations Management, 19(1), pp. 81-96.

Gavronski, I., Klassen, R.D., Vachon, S., and Nascimento, L.F.M.D. (2011). A resource-based view of green supply management. Transportation Research Part E: Logistics and Transportation Review, 47(6), pp. 872-885.

Gill, L., and White, L. (2009). A critical review of patient satisfaction. Leadership in Health Services, 22(1), pp. 8-19.

Gomes, P. (2011). Surgical robotics: Reviewing the past, analysing the present, imagining the future. Robotics and ComputerIntegrated Manufacturing, 27(2), pp. 261-266.

Goodman, S., and Jones, C. (2013). Hospitals and Suppliers: Become a Partner of Choice, Gallup Business Journal, 2013 (Dec-17).

Goldstein, S. M., Ward, P. T., Leong, G. K., \& Butler, T. W. (2002). The effect of location, strategy, and operations technology on 
hospital performance. Journal of Operations Management, 20(1), pp. 63-75.

Graban, M. (2011). Lean Hospitals: Improving Quality, Patient Safety, and Employee Satisfaction, Taylor, and Francis, Boca Raton, Florida.

Graetz, I., Reed, M., Shortell, S.M., Rundall, T.G., Bellows, J., and Hsu, J. (2014). The Association between EHRs and Care Coordination Varies by Team Cohesion. Health Services Research, 49(1), pp. 438-452.

Gunasekaran, A., Patel, C., and Mcgaughey, R.E. (2004). A framework for supply chain performance measurement. International Journal of Production Economics, 87(3), pp. 333-347.

Hammervoll, T. (2011). Honeymoons in supply chain relationships: The effects of financial capital, social capital and psychological commitment. The International Journal of Logistics Management, 22(2), pp. 264-279.

Handfield, R. (2010). Non-Healthcare Supply Chain Tools for the Healthcare Problem, Supply Chain Resource Cooperative, Raleigh, NC.

Harper, P. R. (2002). A Framework for Operational Modelling of Hospital Resources. Health Care Management Science, 5(3), pp. 165-173.

Hay, J. W. (2003). Hospital cost drivers: an evaluation of 19982001 state-level data. The American Journal of Managed Care, 9(1), pp. 13-24.

Heineke, J. (1995). Strategic operations management decisions and professional performance in U.S. HMOs. Journal of Operations Management, 13(4), pp. 255-272.

Hendricks, K.B., Singhal, V.R., and Stratman, J.K. (2007). The impact of enterprise systems on corporate performance: A study of ERP, SCM, and CRM system implementations. Journal of Operations Management, 25(1), pp. 65-82.

Hirano, H. (1995). 5 Pillars of the Visual Workplace, Productivity Press, Cambridge, Massachusetts.

Huang, S. S., Avery, T. R., Song, Y., Elkins, K. R., Nguyen, C. C., Nutter, S. K., Nafday, A. A., Condon, C. J., Chang, M. T., Chrest, D., Boos, J., Bobashev, G., Wheaton, W., Frank, S. A., Platt, R., Lipsitch, M., Bush, R. M., Eubank, S., Burke, D. S., and Lee, B. Y. (2010). Quantifying interhospital patient sharing as a mechanism for infectious disease spread. Infection Control \& Hospital Epidemiology, 31(11), pp. 1160-1169.

Hu, Q., and Schwarz, L.B. (2011). Controversial Role of GPOs in Healthcare-Product Supply Chains. Production and Operations Management, 20(1), pp. 1-15.

Hu, Q., Schwarz, L.B., and Uhan, N.A. (2012). The Impact of Group Purchasing Organizations on Healthcare-Product Supply Chains. Manufacturing, and Service Operations Management, 14(1), pp. 7-23.

Huber, G.P., and Mcdaniel, R.R. (1986). The decision-making paradigm of organizational design. Management Science, 32(5), pp. 572-589.

Hudelson, P., Cleopas, A., Kolly, V., Chopard, P., and Perneger, T. (2008). What is quality and how is it achieved? Practitioners' views versus quality models. BMJ Quality \& Safety, 17(1), pp. 31-36.

Janda, S., Murray, J.B., and Burton, S. (2002). Manufacturersupplier relationships: An empirical test of a model of buyer outcomes. Industrial Marketing Management, 31(5), pp. 411420.

Jarousse, L.A. (2016). Information Governance for Hospitals. Hospitals and Health Networks. H\&HN Magazine, AHA, Chicago, IL.

Jha, A.K., Desroches, C.M., Campbell, E.G., Donelan, K., Rao, S.R., Ferris, T.G., Shields, A., Rosenbaum, S., and Blumenthal, D. (2009). Use of Electronic Health Records in U. S. Hospitals. New England Journal of Medicine, 360(16), pp. 1628-1638.

Johnston, C.A., and Rooney, C.D. (2012). GPOs and the health care supply chain: market-based solutions and real-world recommendations to reduce pricing secrecy and benefit health care providers. Journal of Contemporary Health Law \& Policy, 29(1), pp. 72-88.

Kaplan, G. S., Patterson, S. H., Ching, J. M., Blackmore, C. C. (2014). Why Lean doesn't work for everyone. BMJ Quality \& Safety, 23(12), pp. 970-973.

Kaynak, H. (1997). Total Quality Management and Just-in-Time Purchasing: Their Effects on Performance of Firms Operating in the US. New York: Garland Publishing Inc.

Kaynak, H. (2002). The Relationship between Just-in-time Purchasing Techniques and Firm Performance. IEEE Transactions on Engineering Management, 49(3), pp. 205217.

Kowalski, J.C. (2009). Needed: A strategic approach to supply chain management. Healthcare Financial Management, 63(6), pp. 90-98.

Krajewski, L., Ritzman, L. P., \& Malhotra, M. K. (2002). Operations Management (8 ed.). Upper Saddle River, NJ: Pearson Prentice Hall.

Kumar, R., and Gandhi, R. (2012). Reasons for cancellation of operation on the day of intended surgery in a multidisciplinary 500 bedded hospital. Journal of Anesthesiology Clinical Pharmacology, 28(1), pp. 66-69.

Labarere, J., Francois, P., Auquier, P., Robert, C., \& Fourny, M. (2001). Development of a French inpatient satisfaction questionnaire. International Journal for Quality in Health Care, 13(2), pp. 99-108.

Langtree, I. (2013). Hospital Departments: Definitions, and Lists, available at: http://www.disabledworld.com/definitions/hospital-departments.php/ (accessed 19 April 2016).

Larson, P.D. (1994). Buyer-Supplier Co-operation, Product Quality and Total Costs. International Journal of Physical Distribution, and Logistics Management, 24(6), pp. 4 - 10.

Lawal, A. K., Rotter, T., Kinsman, L., Sari, N., Harrison, L., Jeffery, C., Kutz, M., Khan, M.F., and Flynn, R. (2014). Lean management in health care: definition, concepts, methodology and effects reported (systematic review protocol). Systematic Reviews (3), pp. 103-108.

LeBrasseur, R., Whissell, R., \& Ojha, A. (2002). Organisational Learning, Transformational Leadership and Implementation of Continuous Quality Improvement in Canadian Hospitals. Australian Journal of Management, 27(2), pp. 141 - 162.

Lee, B. Y., McGlone, S. M., Song, Y., Avery, T. R., Eubank, S., Chang, C.C., Bailey, R.R., Wagener, D.K., Burke, D.S., Platt, R., and Huang, S. S. (2011). Social Network Analysis of Patient Sharing Among Hospitals in Orange County, California. American Journal of Public Health, 101(4), pp. 707-713.

Lee, B. Y., Wong, K. F., Bartsch, S. M., Yilmaz, S. L., Avery, T. R., Brown, S. T., Song, Y., Singh, A., Kim, D. S., and Huang, S. S. (2013). The Regional Healthcare Ecosystem Analyst (RHEA): a simulation modeling tool to assist infectious disease control in a health system. Journal of the American Medical Informatics Association, 20(e1), pp. e139-146.

Leidner, D.E., Preston, D., and Chen, D. (2010). An examination of the antecedents and consequences of organizational IT innovation in hospitals. The Journal of Strategic Information Systems, 19(3), pp. 154-170.

Li, S., and Lin, B. (2006). Accessing information sharing and information quality in supply chain management. Decision Support Systems, 42(3), pp. 1641-1656.

Li, S., Rao, S.S., Ragu-Nathan, T.S., and Ragu-Nathan, B. (2005). Development and validation of a measurement instrument for studying supply chain management practices. Journal of Operations Management, 23(6), pp. 618-641.

Lumineau, F., and Henderson, J.E. (2012). The influence of relational experience and contractual governance on the negotiation strategy in buyer-supplier disputes. Journal of 
Operations Management, 30(5), pp. 382-395.

Mackelprang, A.W., and Nair, A. (2010). Relationship between just-in-time manufacturing practices and performance: A meta-analytic investigation. Journal of Operations Management, 28(4), pp. 283-302.

Macrae, M. (2013). Top 5 Medical Technology Innovations, available at: https://www.asme.org/engineeringtopics/articles/bioengineering/top-5-medical-technologyinnovations/ (accessed 19 April 2016).

Marley, K.A., Collier, D.A., and Meyer Goldstein, S. (2004). The Role of Clinical and Process Quality in Achieving Patient Satisfaction in Hospitals. Decision Sciences, 35(3), pp. 349369.

Martin, G.S. (2014). Does your healthcare provider know you?, available http://www.northeastern.edu/news/2014/02/patienthealthcare-provider-relationship/ (accessed 19 April 2016).

McFadden, K.L., Jung Young, L.E.E., Gowen Iii, C.R., and Sharp, B.M. (2014). Linking Quality Improvement Practices to Knowledge Management Capabilities. Quality Management Journal, 21(1), pp. 42-58.

Mckone-Sweet, K.E., Hamilton, P., and Willis, S.B. (2005). The Ailing Healthcare Supply Chain: A Prescription for Change. Journal of Supply Chain Management, 41(1), pp. 4-17.

McLaughlin, C. P., McLaughlin, C., \& Kaluzny, A. D. (2004). Continuous Quality Improvement in Health Care: Theory, Implementation, and Applications: Jones and Bartlett.

Monden, Y. (1981). What makes the Toyota production system really tick?. Industrial Engineering, 13(1), pp. 36-46.

Nelson, C.W., and Niederberger, J. (1990). Patient satisfaction surveys: An opportunity for Total quality improvement. Hospital, and Health Services Administration, 35(3), pp. 409.

Noordewier, T.G., John, G., and Nevin, J.R. (1990). Performance outcomes of purchasing arrangements in industrial buyervendor relationships. Journal of Marketing, 54(4), pp. 80-93.

Ōno, T. (1988). Toyota Production System: Beyond Large-scale Production, Productivity Press, New York, New York.

Paterson, W.G., T Depew, W., Pare, P., Petrunia, D., Switzer, C., Van Zanten, S.J.V., Daniels, S., and Canadian Assoc, G. (2006). Canadian consensus on medically acceptable wait times for digestive health care. Canadian Journal of Gastroenterology, 20(6), pp. 411-423.

Peters, D. H. (2014). The application of systems thinking in health: why use systems thinking? Health Research Policy and Systems, 12(1), pp. 51-56.

Petersen, K., and Wohlin, C. (2011). Measuring the flow in lean software development. Software: Practice and Experience, 41(9), pp. 975-996.

Pittet, D., Hugonnet, S., Harbarth, S., Mourouga, P., Sauvan, V., Touveneau, S., Perneger, T.V., and Infection Control, P. (2000). Effectiveness of a hospital-wide programme to improve compliance with hand hygiene. Lancet, 356(9238), pp. 1307-1312.

Queenan, C.C., Angst, C.M., and Devaraj, S. (2011). Doctors' orders-If they're electronic, do they improve patient satisfaction? A complements/substitutes perspective. Journal of Operations Management, 29(7-8), pp. 639-649.

Rivard-Royer, H., Landry, S., and Beaulieu, M. (2002). Hybrid stockless: A case study Lessons for health-care supply chain integration. International Journal of Operations, and Production Management, 22(4), pp. 412-424.

Rohner, P., and Mettler, T. (2010). Hospital Supplier Relationship Management: Cooperation, Coordination, and Communication. International Journal of Applied Logistics, 1(3), pp. 44-61.

Saeed, K.A., Malhotra, M.K., and Grover, V. (2005). Examining the Impact of Interorganizational Systems on Process Efficiency and Sourcing Leverage in Buyer-Supplier Dyads. Decision Sciences, 36(3), pp. 365-396.

Schneider, H., \& Mathios, A. (2006). Principal Agency Theory and
Health Care Utilization. Economic Inquiry, 44(3), pp. 429441.

Schneller, E.S., and Smeltzer, L.R. (2006). Strategic Management of the Health Care Supply Chain, Wiley, San Francisco, CA.

Schroeder, M. (2015). Hospitals Are Moving (Slowly) to Electronic Medical Records. U.S. News, 15 October 2015.

Shah, R., and Ward, P.T. (2003). Lean manufacturing: context, practice bundles, and performance. Journal of Operations Management, 21(2), pp. 129-149.

Singh, M., Rice, J., and Riquier, D. (2006). Transforming the Global Health Care Supply Chain. MIT Center for Transportation and Logistics.

Sloan, T., Fitzgerald, A., Hayes, K. J., Radnor, Z., and Sohal, S. R. (2014). Lean in healthcare - history and recent developments. Journal of Health Organization and Management, 28(2), pp. 130-134.

Starfield, B. (2000). Is US health really the best in the world?. The Journal of the American Medical Association, 284(4), pp. 483-485.

Sugimori, Y., Kusunoki, K., Cho, F., and Uchikawa, S. (1977). Toyota production system and Kanban system Materialization of just-in-time and respect-for-human system. International Journal of Production Research, 15(6), pp. 553.

Sui-Ppheng, L., and Khoo, S.D. (2001). Team performance management: enhancement through Japanese 5-S principles. Team Performance Management, 7(8), pp. 105 - 111.

Talluri, S., and Sarkis, J. (2002). A model for performance monitoring of suppliers. International Journal of Production Research, 40(16), pp. 4257-4269.

Toussaint, J.S., and Berry, L.L. (2013). The Promise of Lean in Health Care. Mayo Clinic Proceedings Mayo Clinic, 88(1), pp. 74-82.

Torrens, P.R. (2010). The Health care Team Members: Who Are They and What do They Do? In Freshman, B., Rubino, L., Chassiakos, Y.R. (Ed.). Collaboration Across the Disciplines in Health Care, Jones, and Bartlett Learning, Sudbury, MA.

Trapero, J.R., Kourentzes, N., and Fildes, R. (2012). Impact of information exchange on supplier forecasting performance. Omega, 40(6), pp. 738-747.

Ulhassan, W., von Thiele Schwarz, U., Thor, J., and Westerlund, H (2014). Interactions between lean management and the psychosocial work environment in a hospital setting - a multimethod study. BMC Health Services Research, 14(1), pp. 480-491.

Vest, J.R., and Gamm, L.D. (2010). Health information exchange: persistent challenges and new strategies. Journal of the American Medical Informatics Association, 17(3), pp. 288294.

Villena, V.H., Revilla, E., and Choi, T.Y. (2013). Antidotes to the Dark Side of Collaborative Buyer-Supplier Relationships. Academy of Management Proceedings, 2013(1).

Wakefield, B.J., Uden-Holman, T., and Wakefield, D.S. (2005). Development and Validation of the Medication Administration Error Reporting Survey Tools, and Products in Henriksen K, Battles JB, Marks ES, et al. (Ed.). Advances in Patient Safety: From Research to Implementation (Volume 4: Programs, Tools, and Products). Agency for Healthcare Research and Quality, Rockville, Maryland.

Waldfogel, S. (2013). How Safe is your hospital?, available at: https://www.newschallenge.org/challenge/healthdata/entries/ how-safe-is-your-hospital-saving-lives-by-eradicatingmedical-errors/ (accessed 19 April 2016).

Ware, J.E., Snyder, M.K., Wright, W.R., and Davies, A.R. (1983). Defining and measuring patient satisfaction with medical care. Evaluation and Program Planning, 6(3-4), pp. 247-263.

Waring, J.J., and Bishop, S. (2010). Lean healthcare: Rhetoric, ritual and resistance. Social Science, and Medicine, 71(7), pp. $1332-1340$

Wearmouth, P. (2001). A first guide to new, modern and 
dependable ward housekeeping services in the NHS. Norwich, UK: NHS Estates.

Whitney, E. (2015). Sharing Patient Records Is Still A Digital Dilemma For Doctors, available at: http://www.npr.org/sections/healthshots/2015/03/06/388999602/sharing-patient-records-is-stilla-digital-dilemma-for-doctors/ (accessed 19 April 2016).

Womack, J.P., and Jones, D.T. (2010). Lean Thinking: Banish Waste and Create Wealth in Your Corporation, Free Press, New York, NY.

Wong, J., Khu, K.J., Kaderali, Z., and Bernstein, M. (2010). Delays in the operating room: signs of an imperfect system. Canadian Journal of Surgery, 53(3), pp. 189-195.

Worldbank (2015). Health expenditure per capita (current US\$). available

at: http://data.worldbank.org/indicator/SH.XPD.PCAP?order= wbapi_data_value_2013+wbapi_data_value+wbapi_data_va lue-last\&sort=desc/ (accessed 19 April 2016).

Zaghloul, A.A.Z., and El Enein, N.Y.A. (2010). Hourly-block and standard patient scheduling systems at two private hospitals in Alexandria. Journal of Multidisciplinary Healthcare (3), pp. 225-232.

Zidel, T. (2006). A Lean Guide to Transforming Healthcare: How to Implement Lean Principles in Hospitals, Medical Offices, Clinics, and Other Healthcare Organizations: Taylor \& Francis.

Dr. Subhajit Chakraborty is an Assistant Professor of Management and Decision Sciences in the E. Craig Wall Sr. College of Business Administration at Coastal Carolina University. He holds a Ph.D. in Business Administration from The University of Texas Rio Grande Valley. He has 11 years of practitioner experience in operations, supply chain and information technology domains with project management and expatriate experience and is a member of the American Society for Quality. His research interests include service quality along firms' supply chain, services design, outsourcing and lean healthcare operations. He received the Best Student Paper award at the DSI 2015 conference and later his dissertation research won the Emerald/EFMD's Highly Commended Award in Operations Management category.

Dr. Jorge A. Gonzalez is an Associate Professor of Management at The University of Texas Rio Grande Valley. He received his Ph.D. in Management from the Mays Business School at Texas A\&M University. His research interests are in diversity in organizations and communities, relationships, leadership, health care management, and cross-cultural organizational behavior. His research has been published in the Journal of International Business Studies, Personnel Psychology, Journal of Organizational Behavior, and Organization Studies, among other journals. He is the recipient of numerous awards such as the Saroj Parasuraman best publication award and the Dorothy Harlow best paper award. 